\title{
Characteristics of Poaceae pollen grains as a tool to assess palaeoecological grassland dynamics in South America
}

\author{
Lisa Schüler · Hermann Behling
}

Received: 19 November 2009/Accepted: 17 May 2010/Published online: 15 September 2010

(C) The Author(s) 2010. This article is published with open access at Springerlink.com

\begin{abstract}
During the Quaternary, in particular during glacial times, different grassland ecosystems played a much larger role and had a significantly larger distribution. Little is known yet about past development, biodiversity and dynamics of grassland ecosystems. In this innovative study, we attempt to distinguish between different South American grassland types in space and time based on morphological pollen grain characteristics of Poaceae. For this purpose $>60-80$ Poaceae pollen grains of 20 grassland samples were measured using their length, width and pore diameter as well as annulus width. Samples were taken from five sites in wet Páramo vegetation from the Late Pleistocene to the Late Holocene in South Ecuador and from two sites in the south-eastern Brazilian highlands (Campos do Altitude) of the same period. Additionally, we investigated two samples from a Pampa site as well as six samples from one Campos grassland site in southern Brazil from the Late Pleistocene to the Late Holocene. Subsets of samples of the Campos grasslands and of the Páramo were investigated in order to retrieve more detailed information on patterns within these vegetation types. Multivariate data analysis of the complete data set shows changes in taxonomic composition along an elevational gradient in the Páramo grasslands. Our results reveal a highly dynamic development of the individual grassland types; they also provide interesting information on Poaceae taxa composition patterns, development and possibly changes in
\end{abstract}

Communicated by A.F. Lotter.

L. Schüler $(\bowtie) \cdot H$. Behling

Department of Palynology and Climate Dynamics, Albrechtvon-Haller Institute for Plant Sciences, Georg-August-University of Göttingen, Untere Karspüle 2, 37073 Göttingen, Germany e-mail: Lisa.Schueler@biologie.uni-goettingen.de biodiversity within these ecosystems. Moreover, our data provide an indication about the origin and dynamics of the Campos ecosystems in the southern Brazilian highlands during the Late Pleistocene and the Holocene before and after the onset of human activities.

Keywords Grasslands $\cdot$ South America $\cdot$ Poaceae $\cdot$ Pollen grain morphology · Grain size · Pampa · Campos · Páramo · Campos de Altitude · Biodiversity

\section{Introduction}

Despite the dominance of grassland ecosystems in South America during the Pleistocene and also despite their high biodiversity, which makes them important for conservation (Behling and Pillar 2008; Overbeck et al. 2005, 2007), these biomes have received little attention so far. In South America different grassland ecosystems covered much larger in areas during the past, in particular during the Pleistocene (Behling and Hooghiemstra 2001). Spatial variations of grassland ecosystems in subtropical and tropical climates as well as changes in composition of grassland vegetation, and locations and shifts of boundaries play an important role in past climate reconstruction (Behling 2002). Furthermore, in order to understand the different grassland areas today, we need to investigate their origin, development and dynamics. Unfortunately, due to the rather uniform morphology of Poaceae pollen grains (Andersen 1979; Beug 1961, 2004) and the very high numbers of species in many regions (Overbeck et al. 2007; Sklenár and Balslev 2005), it has been very difficult, if not even impossible so far, to relate past grassland types to known grassland communities. Since the pollen grain morphology of Poaceae is mostly uniform, it does not 
allow the determination of pollen grains down to subfamily level in most cases. Pivotal details only become visible using a 600-1,000× magnification and oil immersion light microscopy. This however is, when aiming at determining a representative amount of grains for many samples, very intricate and time-consuming. We collected data on measurable parameters of pollen grains to develop a rather quick and effective method to distinguish between grassland communities.

Earlier results reveal that cereal pollen grains can be distinguished from wild grass pollen grains when using a combination of the criterion of grain diameter and the criterion of pore diameter (Andersen 1979; Beug 1961, 1992, 1994; Joly et al. 2007). However, these authors assumed that a characterization of grassland types by the use of Poaceae pollen grains was not possible due to the fairly large number of grains they studied which revealed a normal distribution of grain size. This was predicted to be the outcome of all investigations of grassland types based on pollen grain measurements on Poaceae (Salgado-Labouriau and Rinaldi 1990a, b).

Nevertheless, it is often observed that specific Poaceae pollen grain types are only found in certain grassland samples. The conspicuously different grain sizes of this plant family add to the impression that there must be apparent differences between grassland ecosystems. In a first study on the development and the application of this approach we showed that it is possible to distinguish between South American grassland types using Poaceae pollen grain size (Schüler and Behling 2010). With our approach we seek to derive more detailed information on palaeograssland dynamics. In this study we aim to show how more detailed information on grassland dynamics can be derived with our approach.

We measured four parameters of Poaceae pollen grains in samples from four different grassland types throughout South America. For a first classification of grasslands and a sufficiently clear separation between them, the mean grain length of a grassland pollen grain type yielded enough information. However, further approaches have shown that the analysis of grain length combined with multivariate data analysis in which all grain size parameters are considered, offers a great potential for more detailed information (Schüler and Behling 2010). The aim was to use these quantifiable morphological characteristics of Poaceae pollen grains in order to investigate resemblances, differences and changes in taxa composition within and among the different grassland types on a spatial and a temporal scale as well as biodiversity patterns. We also intended to relate environmental change as well as anthropogenic influence to our outcome, two factors that are known to play an important role (Behling 1997, 1998, 2002; Behling et al. 2004; Belsky 1992; Prieto 1996; Safford 2001;
Vigglizzo and Frank 2006). As a particular question we analyzed the development of the Campos grasslands. We want to give a more detailed insight into the yet unsolved issue of the origin of the Campos, which is still under controversial discussion (Behling et al. 2004; Pinillos and Sarmiento, pers. comm). Based on our data we also want to investigate whether there is a tendency in grain size parameters to vary along an elevational gradient in the Páramo of samples of about the same age. The PleistoceneHolocene transition will be investigated based on the data from the Campos in southern Brazil as well as the dynamics during the Holocene before and after the onset of human activities. Human activities as well as climate change are driving forces for vegetation change, which are very evident in common palynological analyses. Can we also detect them in the composition of Poaceae pollen grain assemblages?

\section{Study sites}

\section{Páramo}

The different study sites (Tables 1,2) within the Páramo vegetation are located in the Podocarpus National Park region, on the western side of the eastern Cordillera (Cordillera Real) in the South Ecuadorian Andes. Here, the Páramo grasslands occur in the uppermost region of the Cordillera above the upper forest line between about 2,800 to $3,700 \mathrm{~m}$ a.s.l. Precipitation rates rise continuously towards the crests of the Cordillera coupled with an increasing wind speed. Precipitation rates attain up to $6,000 \mathrm{~mm}$ per year at $3,100 \mathrm{~m}$ a.s.l.; in crest regions (3,400-3,600 $\mathrm{m}$ a.s.1.) precipitation rates of $>8,000 \mathrm{~mm}$ per year are assumed. Temperature varies according to time of day and season (for Reserva Biologíca San Fransisco (RBSF), South Ecuador: Bendix et al. 2008). The mean annual temperature for the Páramo is $6.5^{\circ} \mathrm{C}$ at $3,400 \mathrm{~m}$ a.s.l. Temperatures below $0^{\circ} \mathrm{C}$ are rare and only occur under anomalous weather conditions at high elevations (San Fransisco area, South Ecuador: Emck 2007). The climate of the Subpáramo and Páramo is diurnal and humid tropical with cold nights and cool days. There is a short dry period between December and March (Bosman et al. 1994). Asteraceae and Poaceae dominate the Páramo flora (Luteyn 1992, 1999; Ramsay 1992; Ricardi et al. 1997). Together they account for one third of all Páramo species in Ecuador (Sklenár and Balslev 2005). The Páramo vegetation does not exceed heights of $3 \mathrm{~m}$. Characteristic species, besides dominating Poaceae species of Calamagrostis, Cortaderia, Festuca and Chusquea (incl. former Neurolepis: Fischer et al. 2009; Boom et al. 2002) are Gynoxys spp. (Asteraceae), Puya eryngioides, P. nitida 
Table 1 Vegetation types and dominant plant species of the four Páramo sites

\begin{tabular}{|c|c|c|}
\hline Site & Páramo type & Dominant species \\
\hline El Tiro & $\begin{array}{l}\text { Subpáramo on the Eastern Cordillera. Present } \\
\text { between } 2,800 \text { and } 3,100 \mathrm{~m} \text { a.s.l. }\end{array}$ & $\begin{array}{l}\text { Puya nitida, Brachyotum rotundifolia, } \\
\text { Ortitrophium peruvianum }\end{array}$ \\
\hline Cerro Toldeo & $\begin{array}{l}\text { Subpáramo/Páramo on the Eastern } \\
\text { Cordillera. Maximum height of vegetation } \\
\text { is } 2 \mathrm{~m}\end{array}$ & $\begin{array}{l}\text { Pyua eryngioides, Chusqua neurophylla, } \\
\text { Monnina arbuscula, Valeriana microphylla, } \\
\text { Chusquea nana, Calamagrostis macrophylla, } \\
\text { Huperzas kuesteri, Halenia, weddelliana } \\
\text { (Brunschön and Behling 2009; Lozano et al. 2003) }\end{array}$ \\
\hline $\begin{array}{l}\text { Laguna Rabadilla } \\
\text { de Vaca }\end{array}$ & $\begin{array}{l}\text { Grass Páramo on the Eastern Cordillera between } 3,100 \\
\text { and } 3,800 \mathrm{~m} \text { a.s.1. Along flat slopes and concave sections. } \\
\text { Herbs and shrubs from } 0.2 \text { to } 1 \mathrm{~m} \text { height }\end{array}$ & $\begin{array}{l}\text { Neurolepis nana, Calamagrostis macrophylla, } \\
\text { Niphogeton dissecta }\end{array}$ \\
\hline Tres Lagunas & Grass Páramo & \\
\hline Laguna Natosas & $\begin{array}{l}\text { Superpáramo on the Eastern Cordillera. Found between } 3,800 \\
\text { and } 4,200 \mathrm{~m} \text { a.s.l., below the lower limit of perpetual snow. } \\
\text { Vegetation cover and diversity reduced }\end{array}$ & $\begin{array}{l}\text { Low rosettes like Draba and Senecio, } \\
\text { mosses and lichens }\end{array}$ \\
\hline
\end{tabular}

Table 2 Site and sample details together with references for pollen diagrams used

\begin{tabular}{|c|c|c|c|c|c|c|}
\hline Site & $\begin{array}{l}\text { Sample } \\
\text { depth }(\mathrm{cm})\end{array}$ & $\begin{array}{l}\text { Cal age } \\
\text { (yrs B.P.) }\end{array}$ & $\begin{array}{l}\text { Present } \\
\text { vegetation }\end{array}$ & $\begin{array}{l}\text { Elevation } \\
\text { (m a.s.1.) }\end{array}$ & Coordinates & References \\
\hline Cambará do Sul & 13 & 150 & Campos & 1,000 & $29^{\circ} 2^{\prime} 14.76^{\prime \prime} \mathrm{S} 50^{\circ} 9^{\prime} 20.24^{\prime \prime} \mathrm{W}$ & Behling et al. 2004 \\
\hline Cambará do Sul & 63 & 1850 & Campos & 1,000 & $29^{\circ} 2^{\prime} 14.76^{\prime \prime} \mathrm{S} 50^{\circ} 9^{\prime} 20.24^{\prime \prime} \mathrm{W}$ & Behling et al. 2004 \\
\hline Cambará do Sul & 95 & 7800 & Campos & 1,000 & $29^{\circ} 2^{\prime} 14.76^{\prime \prime} \mathrm{S} 50^{\circ} 9^{\prime} 20.24^{\prime \prime} \mathrm{W}$ & Behling et al. 2004 \\
\hline Cambará do Sul & 125 & 22630 & Campos & 1,000 & $29^{\circ} 2^{\prime} 14.76^{\prime \prime} \mathrm{S} 50^{\circ} 9^{\prime} 20.24^{\prime \prime} \mathrm{W}$ & Behling et al. 2004 \\
\hline Cambará do Sul & 180 & 41930 & Campos & 1,000 & $29^{\circ} 2^{\prime} 14.76^{\prime \prime} \mathrm{S} 50^{\circ} 9^{\prime} 20.24^{\prime \prime} \mathrm{W}$ & Behling et al. 2004 \\
\hline Cambará do Sul & 210 & 46020 & Campos & 1,000 & $29^{\circ} 2^{\prime} 14.76^{\prime \prime} \mathrm{S} 50^{\circ} 9^{\prime} 20.24^{\prime \prime} \mathrm{W}$ & Behling et al. 2004 \\
\hline Cerro Toledo & 60 & 530 & Páramo & 3,148 & $04^{\circ} 22^{\prime} 28.6^{\prime \prime} \mathrm{S} 079^{\circ} 06^{\prime} 41.5^{\prime \prime} \mathrm{W}$ & Brunschön and Behling 2009 \\
\hline Rabadilla de Vaca & 50 & 830 & Páramo & 3,312 & $04^{\circ} 15^{\prime} 19.7^{\prime \prime} \mathrm{S} 079^{\circ} 06^{\prime} 43.7^{\prime \prime} \mathrm{W}$ & Niemann et al. 2009 \\
\hline Tres Lagunas & 25 & 1000 & Páramo & 3,788 & $03^{\circ} 02^{\prime} 50.9^{\prime \prime} \mathrm{S} 079^{\circ} 14^{\prime} 29.9^{\prime \prime} \mathrm{W}$ & Unpubl. \\
\hline El Tiro & 85 & 12460 & Páramo & 2,817 & $03^{\circ} 59^{\prime} 23.2^{\prime \prime} \mathrm{S} 079^{\circ} 08^{\prime} 42.7^{\prime \prime} \mathrm{W}$ & Niemann and Behling 2008 \\
\hline El Tiro & 101 & 13070 & Páramo & 2,811 & $03^{\circ} 59^{\prime} 23.2^{\prime \prime} \mathrm{S} 079^{\circ} 08^{\prime} 42.7^{\prime \prime} \mathrm{W}$ & Niemann and Behling 2008 \\
\hline El Tiro & 108 & 14620 & Páramo & 2,811 & $03^{\circ} 59^{\prime} 23.2^{\prime \prime} \mathrm{S} 079^{\circ} 08^{\prime} 42.7^{\prime \prime} \mathrm{W}$ & Niemann and Behling 2008 \\
\hline El Tiro & 125 & 23600 & Páramo & 2,817 & $03^{\circ} 59^{\prime} 23.2^{\prime \prime} \mathrm{S} 079^{\circ} 08^{\prime} 42.7^{\prime \prime} \mathrm{W}$ & Niemann and Behling 2008 \\
\hline Laguna Natosas & 40 & $\sim 2000$ & Páramo & 3,482 & $04^{\circ} 43^{\prime} 56.6^{\prime \prime} \mathrm{S} 079^{\circ} 25^{\prime} 41.2^{\prime \prime} \mathrm{W}$ & Villot et al. unpubl. \\
\hline
\end{tabular}

(Bromeliaceae), Hypericum decandrum (Hypericaceae), Rhynchospora vulcani (Cyperaceae), Bejaria resinosa, Disterigma pentandrum, Gaultheria erecta, G. reticulata and Vaccinium floribundum (Ericaceae), Escallonia myrtilloides (Grossulariaceae), Brachyotum andreanum (Melastomataceae), Monnina arbuscula (Polygalaceae), Valeriana microphylla and V. plantaginea (Valerianaceae). In all Páramos ranging from Costa Rica to Ecuador 56 genera and 292 species of Poaceae are known.

\section{Campos}

The Campos grasslands are found in the highlands of southern Brazil between 500 and 1,400 m a.s.l., where they occur within a mosaic with Araucaria forest, as well as in the lowland of Rio Grande do Sul in southern Brazil (Behling 1998, 2002; Behling et al. 2004). The climate of the area of Cambará do Sul, where all samples of this grassland type were obtained, is defined as subtropical and humid without marked dry periods (Nimer 1989). The mean annual rainfall is rather high with $1,400-2,400 \mathrm{~mm}$ per year. Mean annual temperatures do not exceed $14.5^{\circ} \mathrm{C}$. Palaeoenvironmental studies from the Araucaria forest and Campos regions of the southern Brazilian highlands have documented large-scale environmental changes during the Late Quaternary. Amongst others (Behling 1998; Behling and Lichte 1997), data from Santa Catarina (Behling 1995) and Paraná (Behling 1997) showed that Campos vegetation was widespread on the highlands throughout the lateGlacial and early to mid-Holocene times. The Campos 
vegetation is highly diverse and can be characterized by non-arboreal species, such as species of the families Poaceae, Cyperaceae, Asteraceae, Apiaceae, Rubiaceae, Fabaceae and Eriocaulaceae (order of importance according to Klein 1978). Within the grasses, genera such as Andropogon, Aristida and Schizachyrium dominate. They are mixed with small shrubs such as Baccharis, Vernonia and Eryngium horridum. The origin of these ecosystems is yet unsolved and debated (Behling et al. 2004; Pinillos and Saramiento pers. comm.).

\section{Campos de Altitude}

This diminutive grassland type is exclusively found at the highest summits, above 1,800-2,000 $\mathrm{m}$ a.s.l., of the southeastern Brazilian highland ranges of the states of Santa Catarina, Sao Paulo, Rio de Janeiro and Minas Gerais in Brazil (Safford 1999). Today, the climate of the Campos de Altitude is cool and humid; however, patterns of precipitation, temperature and frost are highly seasonal. Pollen records have shown that Campos de Altitude vegetation has been present at least since the Late Pleistocene (Behling 1995, 1998; Behling unpubl.). During the last decades, these ecosystems have been impacted by grazing and anthropogenic fires. This has probably led to the modern structure of vegetation communities displaying a mosaic of shrubs (especially species of Baccharis, Vernonia, various Eupatorieae, Tibouchina, Leandra, and Myrtaceae), small trees (e.g. Escallonia, Weinmannia, Myrsine, Symplocos, Maytenus and Roupala) and continuous covers of bunch grasses (Cortaderia, Calamagrostis and Andropogon) and bamboo (Chusquea spp.) with a sparse understory of pteridophytes and herbs.

\section{Pampa}

The Pampa grasslands are located in eastern Argentina between $31^{\circ}$ and $39^{\circ} \mathrm{S}$ (Cabrera 1968). The present vegetation is mostly characterized by crop farming and small forest plantations. Despite being the result of natural factors as well as agricultural and grazing activities during the past 100 years, it is still possible to find grassland relicts that resemble original grassland communities (León et al. 1984). Before the onset of anthropogenic activities, the dominant vegetation of the Pampas was treeless grassland, dominated by the steppe grasses Stipa and Piptochaetium, with edaphic shrub communities. In the southeastern part of the Pampa the predominant grass species is Paspalum quadrifolium; several species of Eryngium (Apiaceae) are also abundant. Shrub communities consist of Colletia paradoxa and Dodonaea viscosa. The Pampas are exclusively found in the subtropical climate zone of South
America. The Argentinean Pampa is characterized by an east-west moisture gradient with increasing continentality towards the northwest (Burgos 1968). The highest precipitation is reached in the northeast at $>900 \mathrm{~mm} /$ year, and the lowest is in the southwest at $<500 \mathrm{~mm} / \mathrm{year}$ (Prieto 1996). Average temperatures in the southwest are between $20^{\circ} \mathrm{C}$ in January and $7^{\circ} \mathrm{C}$ in July.

\section{Material and methods}

Material

In addition to our full data set of 20 samples from four grassland types (Schüler and Behling 2010), here we analysed individual subsets of samples (Table 2). These were six samples from the Campos site Cambara do Sul in the highlands of southern Brazil, four samples from Páramo vegetation in southern Ecuador which are all dated to the Late Holocene and another four samples dated to different ages in the Late Pleistocene from the Páramo site El Tiro, southern Ecuador.

The selection of samples taken within a core was based on the predominance of grassland vegetation as assumed from existing pollen diagrams from the study sites (Pampa: Prieto 1996; Campos: Behling et al. 2004; Páramo: Brunschön and Behling 2009; Niemann et al. 2009; Campos de Altitude: Behling unpubl.). The radiocarbon age of the samples was calibrated with the CalPal online software (Danzeglocke et al. 2009).

\section{Methods}

For size analysis of pollen grains it is essential that all samples are subject to identical chemical and physical treatment. The preparation of samples was done according to the standard method described by Fægri and Iversen (1989). For all Poaceae pollen grains the same four parameters were measured: length (PL), width (PW), pore diameter (PD) and annulus width (AW). In order to achieve a representative number of pollen grains per sample, we measured at least 60 to 80 pollen grains per sample.

\section{Data analysis}

We conducted a principle component analysis (PCA) of the full data set. No data transformation was applied and the grain parameter scores were centred (by species) and standardized to allow the comparability of measurement data. In order to visualize the trend in grain size, a LOESS model $(\alpha=0.25)$ was fitted on the PCA scores based on 
the pollen grain length and the PCA scores were surrounded by envelopes (marking the outline of scores represented by the extreme values of one data set) according to their affiliation. For the analysis of the temporal dynamic of the Campos grassland in Cambará do Sul, we plotted the grain size parameters against the time scale. All samples taken from Cambará do Sul were considered in this analysis. These samples are dated to 150, 1850, 7810, 22630, 41930 and 46020 cal yrs B.P.

For studying the spatial relationship of Poaceae pollen grain size along an elevational gradient in the Páramo, we selected four samples which are all dated to the Late Holocene (Cerro Toledo, Rabadilla de Vaca, Tres Lagunas and Laguna Natosas) and plotted the pollen grain size parameters against altitude.

\section{Results}

Spatial trend in South American grasslands

The PCA based on the full dataset with samples from Páramo, Campos, Campos de Altitude and Pampa shows differences between the grassland types (Fig. 1). The modelled distribution follows a gradient along the first ordination axis (74.0\%). The far right position of the Páramo scores is very conspicuous, here the largest pollen grains $(>55 \mu \mathrm{m})$ are found. Also, the highest score density is shifted into the range of larger pollen grains $(40-50 \mu \mathrm{m})$. The smallest grass pollen grains $(\sim 15 \mu \mathrm{m})$ belong to the Campos. The range of the Campos sample scores is smaller compared to the Páramo, the highest density of scores is found between 25 and $35 \mu \mathrm{m}$. The scores of the Pampa samples are located within the Campos. However, their range is much smaller, both on the first and on the second PCA axis. The same applies for the Campos de Altitude scores, which feature a slightly broader range than the Pampa scores, but are still well positioned within the central Campos scores. Additionally, one outlier with a large grain size is found in the Campos de Altitude. It is noteworthy that the scores of Campos, Campos de Altitude and Pampa are much more similar to each other than the Páramo scores are to any of them.

Spatial and temporal trends in the Páramo

The response of grain size parameters along an elevational gradient in the Páramo grasslands (Fig. 2) shows the tendency for grain length and grain width to increase between 3,150 and 3,480 $\mathrm{m}$ a.s.l. While the mean length of pollen grains is about $42 \mu \mathrm{m}$ at $3,150 \mathrm{~m}$ a.s.l., it goes up to $48 \mu \mathrm{m}$ when reaching the $3,500 \mathrm{~m}$ a.s.l. mark. The same applies to the grain width, the pore diameter and the annulus width. For the latter two this increase is only a minor trend. Above 3,500 $\mathrm{m}$ a.s.l., all grain size parameters decrease rapidly again. Pore diameter and annulus width show this tendency only to a small extent, while grain length and grain width show a strong decrease in size down to 38 and $33 \mu \mathrm{m}$ respectively in the sample from Tres Lagunas at $3,790 \mathrm{~m}$ a.s.l.

The ordination plot of the samples from El Tiro during the Late Glacial period (Fig. 3) shows similar score distributions for the oldest $(23610 \mathrm{cal} \mathrm{yrs} \mathrm{B.P.)} \mathrm{and} \mathrm{the}$ youngest $(12460 \mathrm{cal}$ yrs B.P.) sample. The position of highest score density in the oldest sample is on the right hand side within the envelope, whereas this position in the youngest samples is found in the centre of its envelope, thus shifted to the left side of the diagram compared to the oldest sample. The score distribution of the sample from 14620 cal yrs B.P. is evidently very different. Scores are found solely in the upper two quadrants (except for one), the distribution range is only half the size of the other three analyzed samples, and is strongly compressed on the first axis. The sample from $13070 \mathrm{cal}$ yrs B.P. shows a stretched score distribution on the second ordination axis and a slightly compressed one on the first axis.

Temporal trends in the Campos in southern Brazil

The pollen grain size in the Campos grassland remains rather stable during pre-Late Glacial maximum times (Fig. 4). At $\sim 46000 \mathrm{cal}$ yrs B.P. the mean grain length appears to be about $30 \mu \mathrm{m}$. Only a slight decrease in pollen grain length and width can be noted in the samples from $42000 \mathrm{cal}$ yrs B.P. and $22600 \mathrm{cal}$ yrs B.P. The pore diameter also remains stable until the Late Pleistocene. The annulus width decreases slightly between the two oldest samples but then picks up in size again at $22600 \mathrm{cal}$ yrs B.P. Based on our data the model predicts a strong increase in grain length and width around the Late Pleistocene-early Holocene transition. The pore diameter reaches a minimum; in contrast, the annulus width attains a maximum. During the Holocene the mean pollen grain length and width decrease rapidly. The annulus width shows the same development. The pore diameter increases steadily in the samples dated to the Holocene.

The comparison between pollen grains of Campos samples from the Holocene and samples from the Pleistocene (Fig. 5a) shows a similar distribution along the first ordination axis. The range of the Holocene samples is, however, slightly larger. On the second ordination axis the distribution of scores of the Pleistocene samples shows a much wider range than that of the Holocene samples. Since this axis is correlated with the annulus width, the 


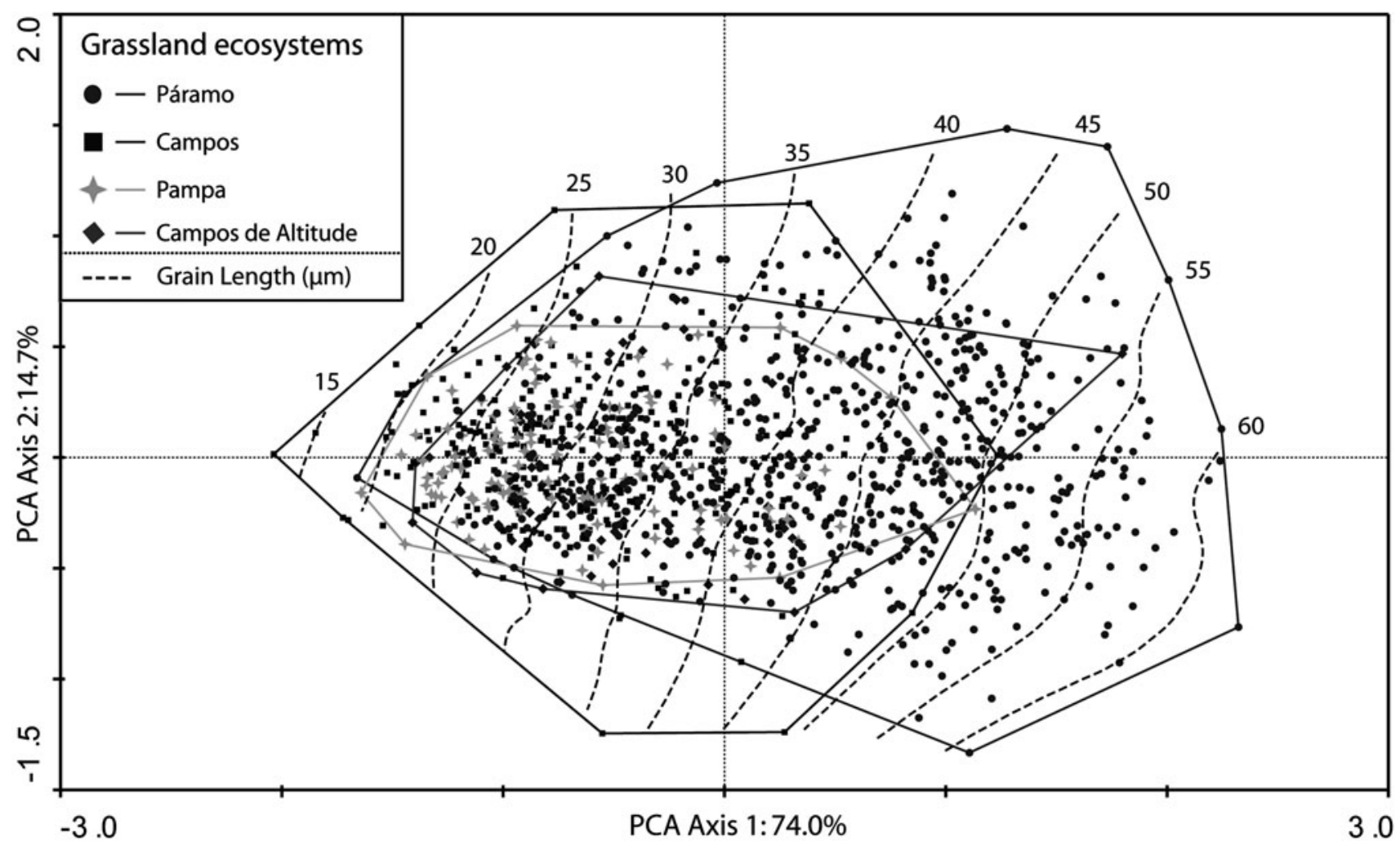

Fig. 1 PCA diagram of the full data set with LOESS model of grain length. The LOESS model shows that the pollen grain length is the major factor responsible for the variability of PCA scores on the first axis

Fig. 2 Response of the Poaceae pollen grain size parameters along an elevational gradient in Páramo vegetation. Values show the average pollen grain size parameters at different elevations and their standard deviation
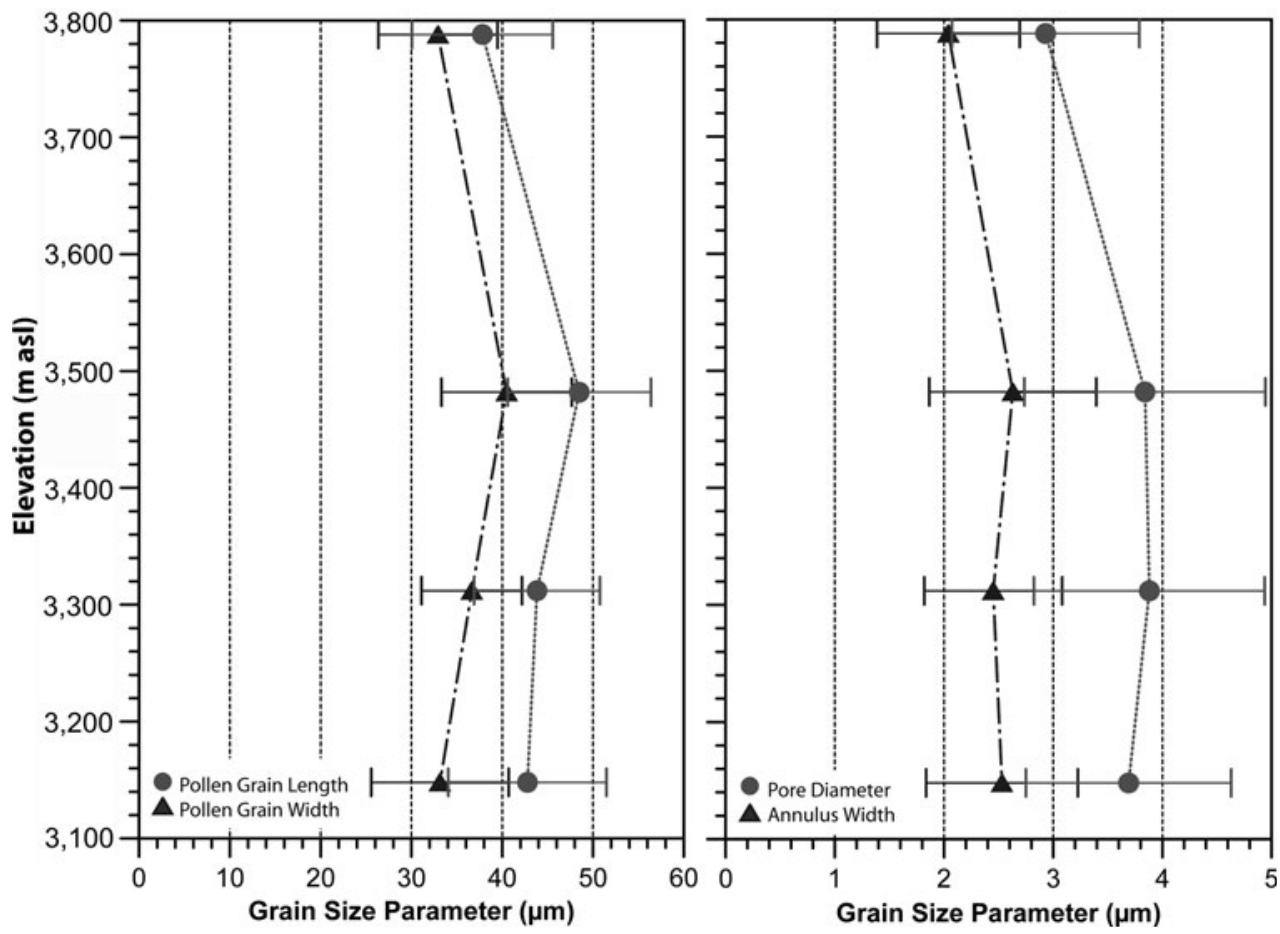

Pleistocene score distribution is influenced by the high variation of annulus width. By contrast, in the Holocene samples the pollen grains appear to vary more in length and width. The pore diameter shows similar correlations with both axes. The position of high score density is similar for the samples from both time spans. 


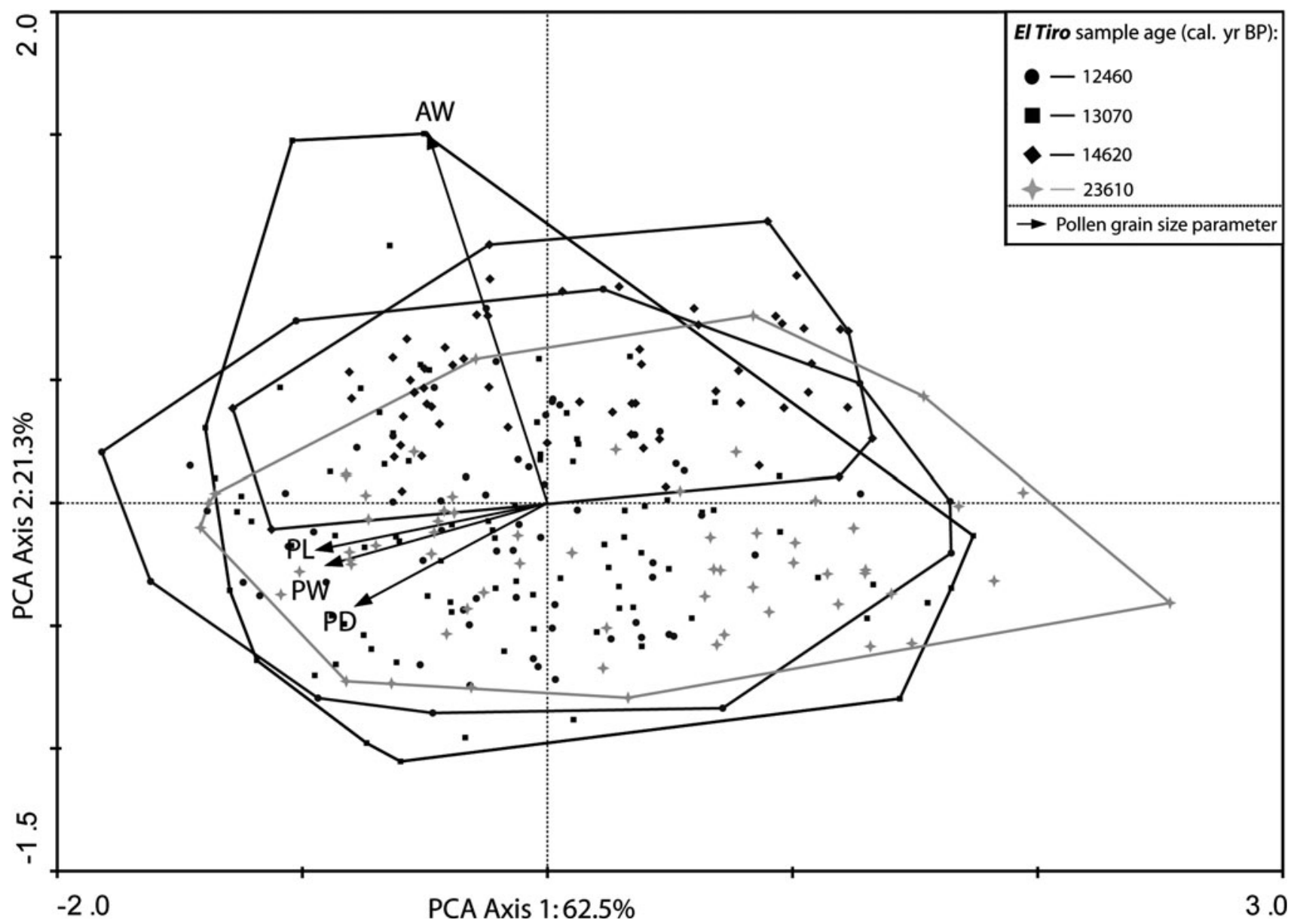

Fig. 3 PCA diagram of the Poaceae pollen samples from El Tiro during the Late Pleistocene. The vectors represent the pollen grain length (PL) and width (PW), the pore diameter (PD) and the annulus width (AW)

The plot of only the Holocene Campos samples shows that the samples from 7810 and $1850 \mathrm{cal}$ yrs B.P. are more similar in position and shape (Fig. 5b). The score distribution of the oldest sample is stretched further on the first ordination axis, yet, more compressed on the second axis. The scores from $1850 \mathrm{cal}$ yrs B.P. sample evidently extend more on the second axis. The most recent sample from $150 \mathrm{cal}$ yrs B.P. is strongly compressed on both axes and its overall score range is much smaller. The position of the highest score density is close to the one found in the sample from $1850 \mathrm{cal}$ yrs B.P.

\section{Discussion}

Our results reveal that it is indeed possible to distinguish between the investigated grassland types in South America and even draw conclusions about patterns on spatial and temporal scales.

Despite the fact that, based on palynological results, we cannot distinguish directly between species or genera within the Poaceae family, we still expect that variations in taxa compositions are reflected in the variation in the grain size parameters. Since the pollen grains of tropical grasses typically show rather little variation in size (Joly et al. 2007), we can draw conclusions about the Poaceae taxa composition based on abundance and mean grain size parameters.

Based on these values, we can make statements on possible changes in taxonomic composition. Since pollen grains do no tend to alter their size or shape within short time periods such as the ones we investigated (except for polyploidization), observed changes in mean values on a time scale or along an elevational gradient has to be related to composition change. Composition change can be either immigration or extinction of taxa, as well as development of taxa to be major (dominant) or minor components of the Poaceae flora in the area.

\section{Spatial trends in South American grasslands}

The multivariate data analysis reveals that in Páramo grasslands Poaceae taxa with large pollen grains dominate 

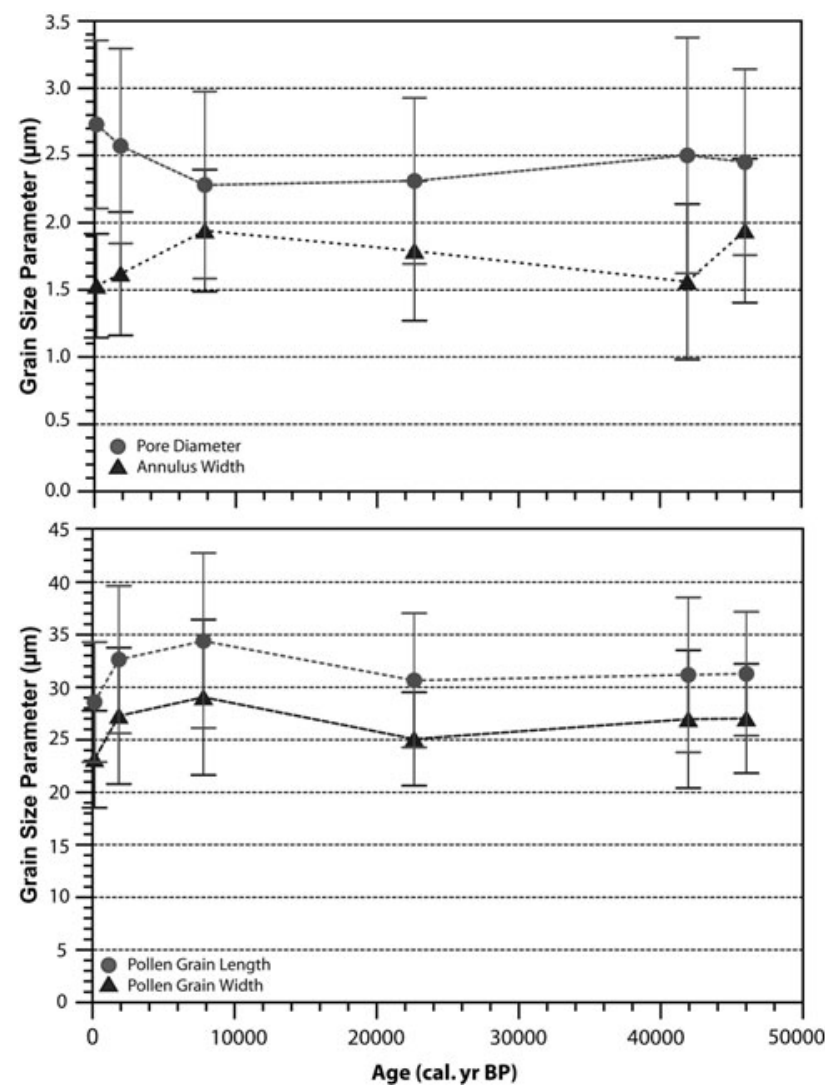

Fig. 4 Changes of the Poaceae pollen grain parameters in the Campos vegetation through time in Cambará do Sul. Values show the average pollen grain size parameters at different ages and their standard deviation

the vegetation. From earlier studies it is known that the subfamilies of woody Bambusoideae and Pooideae often have large pollen grains (Salgado-Labouriau and Rinaldi 1990a). Both subfamilies are well represented in Páramo vegetation as is known from vegetation studies (Homeier et al. 2008) in southern Ecuador, where it was found that e.g. Chusquea (including Neurolepis according to Fischer et al. 2009) is very abundant. Poaceae taxa with very small pollen grains are not present in grass-Páramo in southern Ecuador according to our results.

For the Campos de Altitude grasslands, our results infer a taxonomic composition of Poaceae that is different from the one found in the Páramo, but similar to the Campos grasslands and the Pampa vegetation. Therefore, our results do not support a distinct resemblance to Páramo vegetation as proposed in earlier studies where these ecosystems are even considered as the "Brazilian Páramos" (Hueck 1966; Safford 1999).

Our results also suggest that the taxonomic resemblances between the Campos and Campos de Altitude as well as Pampa are much greater than such resemblances between Campos and Páramo. For the latter two ecosystems the taxonomic composition based on Poaceae pollen grain size parameters suggests strong differences in taxa presence and dominance. This supports the assumption that the Campos are rather a derivative of geographically close grassland ecosystems (Behling et al. 2004) than that of Páramo regions in the northern Andes. We propose that during a cooling event species better adapted to warmer temperatures migrated north and down slope. This applies especially to species that existed in the southern Pampa region and to species at higher elevations in the Campos de Altitude. Poaceae species that migrated and adjusted their distribution to cooler climates probably form the Campos taxa assemblage of today.

Spatial and temporal trends in the Páramos in Ecuador

In the Páramo the pollen grain size parameters suggest profound changes in taxa composition accompanying the climb along the elevational gradient. At 3,400 to 3,500 m a.s.l., the taxa composition must evidently be different to the one below and above. Along the elevational gradient the grain size parameters suggest that Poaceae cannot simply be considered in one single Páramo type. It is evident that a distinction between the Páramo types has to be made. Therefore, it is important to compare the results of the data analysis of Poaceae of the El Tiro site not primarily with the true Páramo vegetation trend to which Poaceae are normally assigned, but rather with the Subpáramo vegetation.

The distribution of $\mathrm{C} 3$ and $\mathrm{C} 4$ grasses also supports our results. It is known, that the percentage of $\mathrm{C} 3$ grasses increases steadily above 2,000 $\mathrm{m}$ a.s.l. in Ecuador (Jørgensen and Ulloa 1994) and replaces the C4 grass species, which are dominant at lower elevations. This is due to the competitive advantage of the $\mathrm{C} 3$ metabolism in wetter and cooler areas. In contrast, $\mathrm{C} 4$ species show higher water use efficiency in more arid and warmer habitats. One explanation for the pattern of grain size along the elevational gradient could be that $\mathrm{C} 4$ dominated Páramo sites are relicts from the Late Glacial as proposed by Boom et al. (2001). Then again the study site of Laguna Natosas $(3,480 \mathrm{~m}$ a.s.l.) is located further to the west, closer to the Inter-Andean Basin. The area is a mosaic of dry and moist places due to the distinctive differences in the relief. Consequently, despite the elevation the percentage of $\mathrm{C} 4$ species could be regionally higher compared to the other sites. Certainly, this pattern could also be due to $\mathrm{C} 3$ taxa that occur at this elevation but do not dominate below or above. However, it remains to be validated that $\mathrm{C} 4$ grasses found there do have larger pollen grains than the present C3 species.

On a temporal scale we can detect one evident change in taxonomic composition at the El Tiro site in Páramo grasslands. The PCA scores before and after the Late 

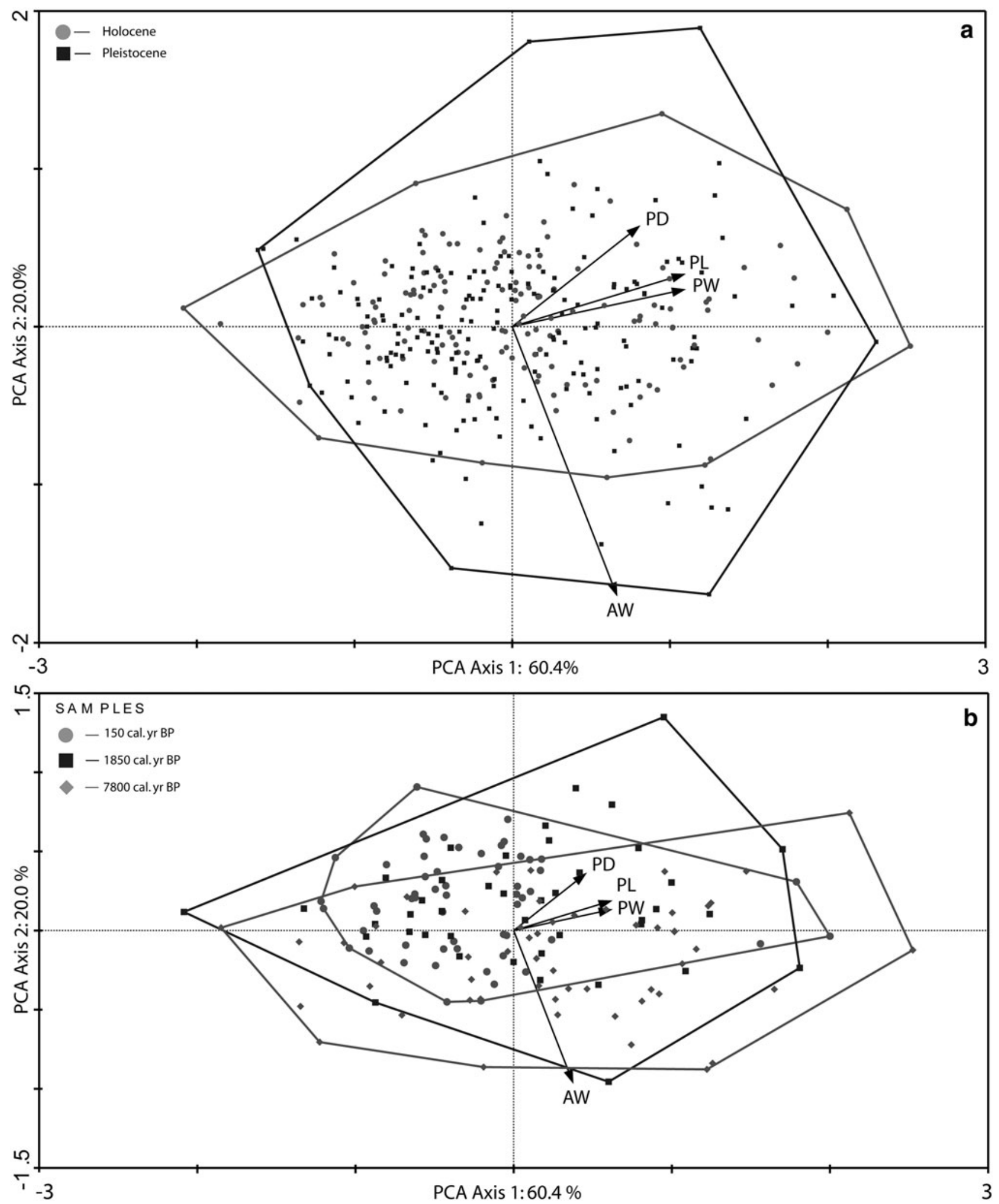

Fig. 5 a PCA diagram of the Campos samples at pre-LGM and post-LGM time periods b PCA diagram of the Holocene Campos samples from Cambará do Sul 
Glacial Maximum (LGM) around $18000 \mathrm{cal}$ yrs B.P. lead to the assumption that a major reduction or regrouping in Poaceae taxa must have occurred during the LGM. Niemann and Behling (2008) found that at the El Tiro site the Subpáramo vegetation became more abundant between 20000 and 16000 cal yrs B.P. Subsequently, the Páramo (2,900-3,400 m a.s.l) vegetation increased strongly whereas the Subpáramo declined. Our findings are concurrent with the temporal patterns of Subpáramo vegetation found by Niemann and Behling (2008). After this strong decline, the Poaceae taxonomic composition in the Subpáramo seems to again approximate the one present during the pre-LGM period. Despite the sample selection from sites with rather similar environmental conditions, differences due to local distinctions cannot be excluded.

\section{Temporal trends in the Campos in southern Brazil}

The older samples from Campos in southern Brazil show a continuous size range of grains which indicate a rather stable taxa composition. In the Late Holocene a conspicuous change in grain size parameters becomes evident. Here, the introduction of cattle into the Campos grasslands (Behling et al. 2004), and hence the increased grazing pressure, could have led to such a profound change in taxa composition. The notable change in grain size parameters of the two samples from the mid and Late Holocene also suggests a clear deviation from the samples dated to the Late Pleistocene. During this period a continuous expansion of Araucaria forest has been observed and is very likely to be the driving force for a change in Poaceae taxa composition. The increased frequency of anthropogenic fires might have also had an influence on this process (Behling et al. 2004), although opposing suggestions have been made (Overbeck et al. 2005).

We can observe a few additional taxa (indicated by pollen with broader grains) in the Campos samples from the Late Holocene, which were not present during the Late Pleistocene. Several seem to have disappeared in the Holocene. Although we cannot ascertain whether there were no additional taxa in the Holocene, we are led to the assumption that the Poaceae biodiversity decreased during the Pleistocene-Holocene transition. In the Campos this loss in biodiversity could be due to increasingly wetter conditions during the Holocene, and subsequently the expansion of Araucaria forest into the grassland areas as well as the onset and intensification of human activities.

However, the majority of taxa remain stable during the Pleistocene and Holocene. Also during the mid Holocene there are only minor shifts of taxonomic composition observable. But then again during the Late Holocene the diversity decreases drastically (Behling et al. 2004, 2007; Behling and Pillar 2007). Behling et al. (2004) suggest that the rapid increase in humidity as well as the migration of Araucaria forests into the Campos during the past 1,000 years caused the decrease of Campos vegetation, and hence the Poaceae. This diminishing trend continues until today, also due to introduced cattle that enhance the replacement of Poaceae taxa by non-foraged plants (Eryngium, Xyris, Senecio, Baccharis, Cyperaceae). Hence, our results reflect the strong species turnover during the Late Holocene.

\section{Conclusion}

Our study provides a range of interesting results and promising sources for future investigations in trying to disentangle interactions and dynamics in South American grassland ecosystems. We show that with the help of Poaceae pollen grain characteristics it is possible to get a considerably more detailed impression of the specific grassland characteristics, their development on a temporal and spatial scale and their response to climate change as well as human impact. Since fine scale responses to climate change take place at species composition levels before affecting ecosystems and vegetation types, even small changes in grassland taxa composition could be used as precursory indications of climate changes on a larger scale. As biological diversity is often regarded as a means for evaluating the stability and consistency of an ecosystem and its environmental factors, observing biodiversity patterns of grasslands could be a tool for monitoring the impact of small scale variation in biotic and abiotic factors, which is eventually necessary for conservation decisions as well as the assessment and prediction of current and future responses of ecosystems to environmental change. Ongoing studies will show whether pollen grain size distributions of Poaceae are consistent and typical for individual grassland ecosystems.

Acknowledgments We would like to thank Aldo Prieto for providing the sediment samples from the Pampa area, hence enabling the comparison of this grassland type with our other investigated areas. Thanks to Petra Lembcke for measuring many of the pollen grains. We appreciated the constructive comments by the reviewers W. Gosling and A. Cleef. We are grateful to A.B. Nielsen who revised the English.

Open Access This article is distributed under the terms of the Creative Commons Attribution Noncommercial License which permits any noncommercial use, distribution, and reproduction in any medium, provided the original author(s) and source are credited.

\section{References}

Andersen ST (1979) Identification of wild grass and cereal pollen. Danmarks Geol Undersøgelse 1978:69-92 
Behling $H$ (1995) Investigations into the Late Pleistocene and Holocene history of vegetation and climate in Santa-Catarina (S Brazil). Veget Hist Archaeobot 4:127-152

Behling H (1997) Late Quaternary vegetation, climate and fire history of the Araucaria forest and campos region from Serra Campos Gerais, Paraná (South Brazil). Rev Palaeobot Palynol 97:109-121

Behling H (1998) Late Quaternary vegetational and climatic changes in Brazil. Rev Palaeobot Palynol 99:143-156

Behling H (2002) South and southeast Brazilian grasslands during Late Quaternary times: a synthesis. Palaeogeogr Palaeoclimatol Palaeoecol 177:19-27

Behling H, Hooghiemstra H (2001) Neotropical Savanna environments in space and time: Late Quaternary interhemispheric comparisons. In: Markgraf V (ed) Interhemispheric climate linkage. Elsevier, Amsterdam, pp 307-323

Behling H, Lichte M (1997) Evidence of dry and cold climatic conditions at glacial times in tropical southeastern Brazil. Quat Res 48:348-358

Behling H, Pillar VD (2007) Late Quaternary vegetation, biodiversity and fire dynamics on the southern Brazilian highland and their implication for conservation and management of modern Araucaria forest and grassland ecosystems. Philos Trans Royal Soc B Biol Sci 362:243-251

Behling H, Pillar VD (2008) Vegetation and fire dynamics in southern Brazil during the Late Quaternary and their implication for conservation and management of modern grassland ecosystems. In: Schroder HG (ed) Grasslands: ecology, management and restoration. Nova Science Publisher, Inc, New York

Behling H, Pillar VD, Muller SC, Overbeck GE (2007) LateHolocene fire history in a forest-grassland mosaic in southern Brasil: Implications for conservation. Appl Veg Sci 10:81-90

Behling H, Pillar VD, Orloic L, Bauermann SG (2004) Late Quaternary Araucaria forest, grassland (Campos), fire and climate dynamics, studied by high-resolution pollen, charcoal and multivariate analysis of the Cambará do Sul core in southern Brazil. Palaeogeogr Palaeoclimatol Palaeoecol 203:277-297

Belsky AJ (1992) Effects of grazing, competition, disturbance and fire on species composition and diversity in grassland communties. J Veget Sci 3:187-200

Bendix J, Rollenbeck R, Richter M, Fabian P, Emck P (2008) Climate. In: Beck E, Bendix J, Kottke I, Makeschin F, Mosandl $\mathrm{R}$ (eds) Gradients in a tropical mountain ecosystem of Ecuador, Ecological studies, 198 edn. Springer, Berlin, Heidelberg, pp 63-73

Beug HJ (1961) Leitfaden der Pollenbestimmung. Fischer, Stuttgart

Beug HJ (1992) Vegetationsgeschichtliche Untersuchungen über die Besiedlung im Unteren Eichsfeld, Landkreis Göttingen, vom frühen Neolithikum bis zum Mittelalter. Neue Ausgrab Forsch Niedersachsen 20:261-339

Beug HJ (1994) Vegetationsgeschichte. In: Hermann B (ed) Archäometrie: Naturwissenschaftliche Analyse von Sachüberresten. Springer, Berlin, Heidelberg, New York, pp 153-168

Beug HJ (2004) Leitfaden der Pollenbestimmung für Mitteleuropa und angrenzende Gebiete. Pfeil, München

Boom A, Mora G, Cleef AM, Hooghiemstra H (2001) High altitude $\mathrm{C} 4$ grasslands in the northern Andes: relicts from glacial conditions? Rev Palaeobot Palynol 115:147-160

Boom A, Marchant R, Hooghiemstra H, Sinninghe Damsté JS (2002) $\mathrm{CO}_{2^{-}}$and temperature-controlled altitudinal shifts of $\mathrm{C} 4-$ and C3-dominated grasslands allow reconstruction of palaeoatmospheric $\mathrm{pCO}_{2}$. Palaeogeogr Palaeoclimatol Palaeoecol 177: $151-168$

Bosman AF, Hooghiemstra H, Cleef AM (1994) Holocene mire development and climatic change from high Andean Plantago ridiga cushion mire. Holocene 3:233-243
Brunschön C, Behling H (2009) Late Quaternary vegetation, fire and climate history reconstructed from two cores at Cerro Toledo, Podocarpus National Park, southeastern Ecuadorian Andes. Quat Res 72:388-399

Burgos JJ (1968) El clima de la Provincia de Buenos Aires en relación con la vegetación y el suelo. In: Cabrera AL (ed) Colección Cientifica INTA, Buenos Aires, pp 33-99

Cabrera AL (1968) Vegetación de la Provincia de Buenos Aires. Flora de la Provincia de Buenos Aires. Colección Cientifíca Parte 1, INTA, Buenos Aires, pp 101-123

Danzeglocke U, Jöris O, Weninger B (2009) CalPal-2007 online, http://www.calpal-online.de/. Accessed 2009-07-17

Emck P (2007) A Climatology of South Ecuador-With special focus on the major Andean Ridge as Atlantic-Pacific climate divide. Doctoral Thesis, University of Erlangen, Nürnberg, pp 108-114

Faegri K, Iversen J (1989) Textbook of pollen analysis. Wiley, Chichester

Fischer AE, Triplett JK, Ho C-S, Schiller AD, Otrogge KA, Schroder ES, Kelchner SA, Clark LG (2009) Paraphyly in the Bamboo Subtribe Chusqueniae (Poaceae: Bambusoideae) and a revised infrageneric classification for Chusquea. Syst Bot 34:673-683

Homeier J, Werner FA, Gradstein SR, Breckle SW, Richter M (2008) potential vegetation and floristic composition of Andean forests in South Ecuador, with a focus on the RBSF. In: Beck E, Bendix J, Kottke I, Makeschin F, Mosandl R (eds) Gradients in a tropical mountain ecosystem of Ecuador. Springer, Heidelberg, Berlin, pp 87-100

Hueck K (1966) Die Wälder Südamerikas. Ökologie, Zusammensetzung und wirtschaftliche Bedeutung. Fischer, Stuttgart

Joly C, Barille L, Barreau M, Mancheron A, Visset L (2007) Grain and annulus diameter as criteria for distinguishing pollen grains of cereals from wild grasses. Rev Palaeobot Palynol 146:221-233

Jørgensen PM, Ulloa C (1994) Seed plants of the high Andes of Ecoador - a checklist. AAU Reports 34

Klein RM (1978) Mapa fitogeográfico do estado de Santa Catarina. Flora Illustrada Catarinense

León RJC, Rusch GM, Oesterheld M (1984) Pastizales pampeanosimpacto agropecuario. Phytocoenologia 12:201-218

Lozano P, Delgado T, Aguirre Z (2003) Estdo actual de la flora endemica exclusive y su distribucion'en el Occidente del Parque Nacional Podocarpus. Funbotanica y Herbario y Jardin Botanico

Luteyn JL (1992) Páramos: why study them. In: Balslev H, Luetyn JL (eds) Páramo: an andean ecosystem under human influence. Academic Press, London, pp 1-14

Luteyn JL (1999) Páramos: a checklist of plant diversity, geographical distribution, and botanical literature. Memories of the New York Botanical Garden, New York, pp 1-278

Niemann H, Behling H (2008) Late Quaternary vegetation, climate and fire dynamics inferred from the El Tiro record in the southeastern Ecuadorian Andes. J Quat Sci 23:203-212

Niemann H, Haberzettl T, Behling H (2009) Holocene climate variability and vegetation dynamics inferred from the (11700 cal. yr B.P. Laguna Rabadilla de Vaca sediment record, southeastern Ecuadorian Andes. Holocene 19:307-316

Nimer E (1989) Climatologia do Brasil. Fundação Instituto Brasileiro de Geografía e Estatística, Rio de Janeiro

Overbeck GE, Müller SC, Pillar VD, Pfadenhauer J (2005) Fine-scale post-fire dynamics in the southern Brazilian suptropical grassland. J Veget Sci 16:655-664

Overbeck GE, Müller SC, Fidelis A, Pfadenhauer J, Pillar VD, Blanco CC, Boldrini II, Both R, Forneck ED (2007) Brazil's neglected biome: the south Brazilian Campos. Persp Plant Ecol Evol Syst 9:101-116

Prieto AR (1996) Late Quaternary vegetational and climatic changes in the Pampa Grassland of Argentina. Quat Res 45:73-88 
Ramsay PM (1992) The páramo vegetation of Ecuador: the community ecology dynamics and productivity of tropical grasslands in the Andes. Doctoral Thesis, University of Wales, Bangor

Ricardi HMS, Gaviria J, Estrada J (1997) La flora del superpáramo venezolano y sus relaciones fitogeográficas a lo largo de los Andes. Plantula 1:171-187

Safford HD (1999) Brazlian Páramos I. An introduction to the physical environment and vegetation of the campos de altitude. J Biogeogr 26:693-712

Safford HD (2001) Brazilian Páramos. III. Patterns and rates of postfire regeneration in the Campos de Altitude. Biotropica 33:281-302

Salgado-Labouriau ML, Rinaldi M (1990a) Measurements of Gramineae pollen of the Venezuelan mountains. Rev Brasil Biol $50: 115-122$
Salgado-Labouriau ML, Rinaldi M (1990b) Palynology of Gramineae of the Venezuelan Mountains. Grana 29:119-128

Schüler L, Behling H (2010) Poaceae pollen grain size as a tool to distinguish past grasslands in South America-a new methodological approach. Veget Hist Archaeobot 20. doi:10.1007/ s00334-010-0265-z

Sklenár P, Balslev H (2005) Superpáramo plant species diversity and phytogeography in Ecuador. Flora 200:416-433

Vigglizzo EF, Frank FC (2006) Ecological interactions, feedbacks, thresholds and collapses in the Argentine Pampas in repsonse to climate and farming during the last century. Quat Int $158: 122-126$ 